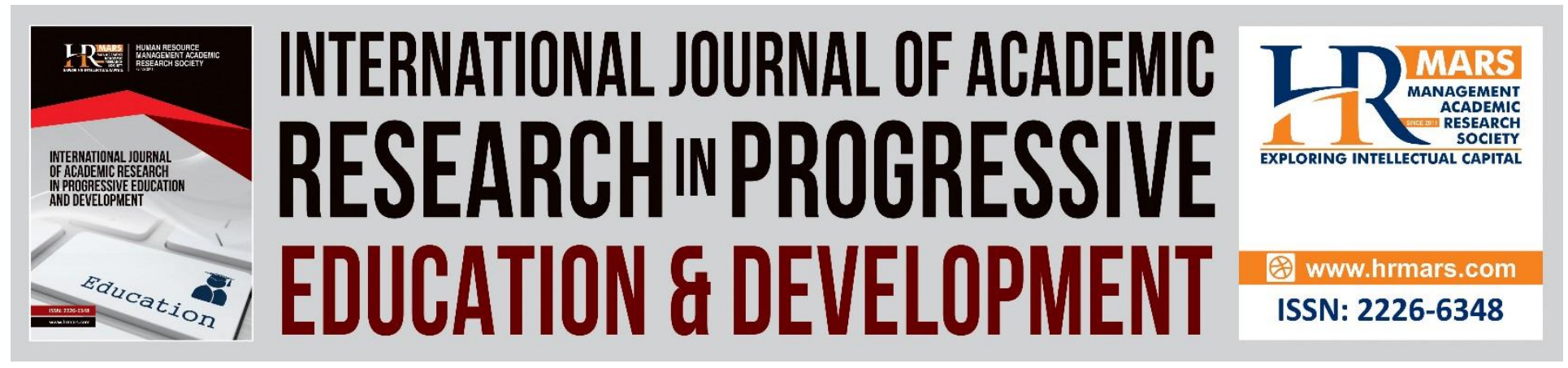

\title{
The Effectiveness of Innovation Kit in Enhancing Tamil National-Type School Students' Mastery in Affixes
}

N Siva Perumal, Vijayaletchumy Subramaniam

To Link this Article: http://dx.doi.org/10.6007/IJARPED/v9-i4/8454

DOI:10.6007/IJARPED/v9-i4/8454

Received: 03 October 2020, Revised: 01 November 2020, Accepted: 17 December 2020

Published Online: 30 December 2020

In-Text Citation: (Perumal \& Subramaniam, 2020)

To Cite this Article: Perumal, N. S., \& Subramaniam, V. (2020). The Effectiveness of Innovation Kit in Enhancing Tamil National-Type School Students' Mastery in Affixes. International Journal of Academic Research in Progressive Education and Development, 9(4), 113-127.

Copyright: (C) 2020 The Author(s)

Published by Human Resource Management Academic Research Society (www.hrmars.com)

This article is published under the Creative Commons Attribution (CC BY 4.0) license. Anyone may reproduce, distribute, translate and create derivative works of this article (for both commercial and non-commercial purposes), subject to full attribution to the original publication and authors. The full terms of this license may be seen at: http://creativecommons.org/licences/by/4.0/legalcode

Vol. 9(4) 2020, Pg. 113 - 127

http://hrmars.com/index.php/pages/detail/IJARPED

JOURNAL HOMEPAGE

Full Terms \& Conditions of access and use can be found at

http://hrmars.com/index.php/pages/detail/publication-ethics 


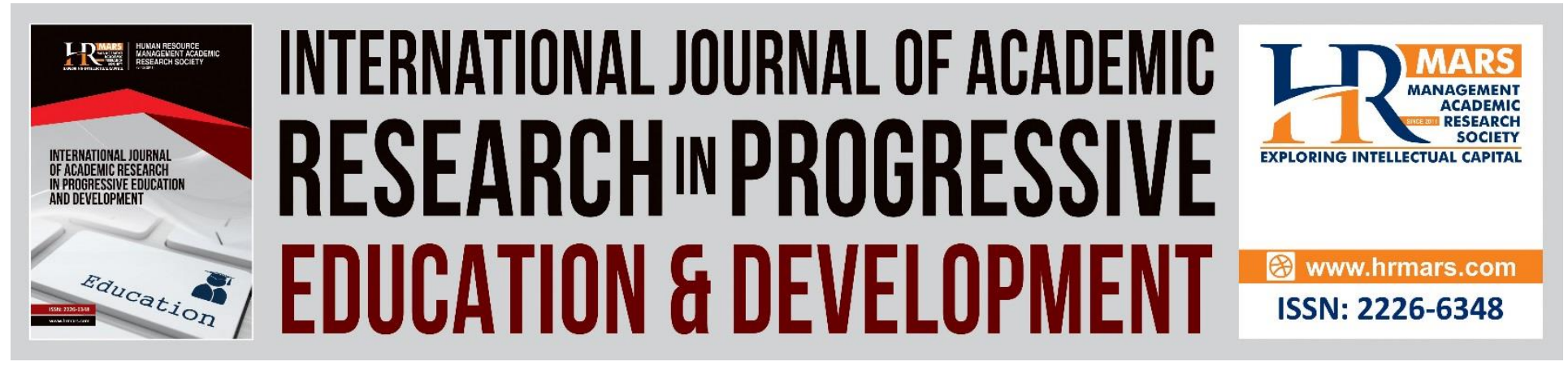

\title{
The Effectiveness of Innovation Kit in Enhancing Tamil National-Type School Students' Mastery in Affixes
}

\author{
N Siva Perumal, Vijayaletchumy Subramaniam, PHD \\ Faculty of Modern Languages and Communication, Universiti Putra Malaysia, Malaysia \\ Email: sivimal18@yahoo.com, vletchumy@upm.edu.my/letchumy1617@gmail.com
}

\begin{abstract}
This study was conducted to evaluate the effectiveness of the affixation innovative kit on the achievement of SJKT student in the area of affixes. The quasi-experimental study was conducted on 68 students from two SJKTs in Klang district, Selangor. They were divided into two groups, 34 students of the experimental group were taught in a planned approach, while the control group of 34 students was taught using the conventional approach. Data were obtained from pre- and post-tests. From the analysis performed, the results show that there is a significant difference in the mean scores of achievement of all aspects of affixes between the experimental group and the control group in the post-test. The mean scores for the students in the sample were high compared to the control group scores in the post test. The findings of this study prove that the strategic use of the affixation innovative kit in teaching and facilitation successfully improved student performance in the area of affixes. The use of the kit can be used as an alternative activity to enhance students' mastery in affixes.

Keywords: Quasi-Experiments, Treatment Groups, Control Groups, Affixation Innovative Kit, Sjkt Students

\section{Introduction}

The Malay Language curriculum that is experiencing revision and improvement issues, has introduced the Malay Language Standard Curriculum for primary schools. The standardised Grammatical Aspect Content formulated aims at determining students' capability in mastering their grammar as fundamental to their language skills. Every student in national-type schools is made compulsory to master types of affixes that have been determined. Year 1 and 2 students should understand and use correct prefixes and suffixes in multiple contexts. Students in Year 3 have to understand and use the prefix meN- and the right affixes in various situations. For level 2 students, yerar 4 students should understand and use the prefixes meN, peN, beR, and teR correctly in contexts. Year 5 students have to understand and use affixes and loan affixes correctly according to context, whereas year 6 students must understand and use various affixes in various situations correctly (Kementerian Pendidikan Malaysia, 2011).
\end{abstract}


Although various efforts have been realised by the government to strengthen the mastery in Malay Language, its achievement at UPSR level for Tamil National-type Schools in Klang district from 2012 to 2016 is still at moderate level (Klang District Education Office, 2017). The percentage of failure in Comprehension and Writing (Bahasa Melayu) in 13 SJKT in Klang district is between $38 \%$ and $46 \%$ in the consecutive 5 years. There should be zero fail percentage in both papers. This despairing statistics gives a great impact towards increasing the quality of mastery in Bahasa Melayu among SJKT students. Most students who enrol in remedial classes at secondary school are Indian students owing to the fact that their mastery in the subject is below par.

Among the factors why SJKT students are weak at mastering Bahasa Melayu are due to the fact that the language is the second language in SJKT, Bahasa Melayu teachers use both languages in the teaching of Bahasa Melayu in the teaching of Bahasa Melayu, and students do not have the initiative to speak in Bahasa Melayu. Affixes are one of the grammar components in Bahasa Melayu. New words are created through the process of affixes. Thus, affixes are often used in Bahasa Melayu either through speeches or writing. Tamil school students have to master affixes because every section of both papers contains affixes elements.

This issue is further proven through a pilot study carried out on 60 average students from four schools. They answered 25 multiple choice questions about prefixes, suffixes, affixes and loan affixes. The finding shows that $76 \%$ students do not master prefixes, $80 \%$ students do not master suffixes, $15 \%$ students mastered affixes and $20 \%$ students master loan affixes. The pilot study clearly shows that there is weak affixes mastery among SJKT students. This finding is in line with the study by Hamid, Badushah \& Sulaiman (2010) whereby $80 \%$ non-Malay students are weak in grammar mastery. The application of interesting teaching aid especially language game techniques can stimulate students' interests to learn BM as the second language (Ali \& Mahamod, 2016).

\section{Study Objective}

The general objective of this study is to compare the effectiveness of the affixation innovative kit with the use of the conventional technique in the teaching and learning of affixes.

\section{Literature Review \\ Studies on Affixes}

The study carried out by Razin \& Subramaniam (2019) details the type of errors concerning prefixes and suffixes based on Corder's Error Analysis Theory (1973). They also carried out the study to identify the reasons why Tamil National-type Schools (SJKT) students are not capable of mastering prefixes and suffixes. A total of 50 Indian students are chosen to be the study sample. The study sample consists of Year 5 students from the Tamil National-type Schools in Serdang. A written test about prefixes and suffixes serves to be an instrument while Corder's Error Analysis Theory (1973) was used as theory. The observation method was also used in this study. The study outcome explains that all students have failed to master prefixes and suffixes. It is a step forward for the students to improve their understanding in affixes so that they will be able to apply the affixes they master in their writing. The study done by Razin \& Subramaniam (2019) has touched on the type of affixes errors committed by Indian students by applying Corder's Error Analysis 
Theory (1973). This study has inspired the researchers to conduct a study about prefixes, suffixes, affixes and loan affixes by using Corder's Error Analysis Theory (1973) and the MultipleIntelligence Theory.

The paper work written by Jumari \& Haron (2018) seeks to overcome the weakness of the use of the prefix beR- and affix beR-...-an through the applications of Nearpod and Google Docs aided by the Active Learning Approach. According to the study, the use of the prefix beR-and affix beR...-an is the point of weakness for students of Form 3 Ekspres in using affixes. This is because only $38 \%$ students were able to answer prefix questions correctly. The study outcome finds that students took part proactively in constructing and gaining knowledge and experiences about the prefix beR- and affix beR-...-an. BM teachers are very satisfied with students who can explain about the meaning of prefix ber- and affix ber-...-an in the context of the sentence conveyed. This can be proven after a survey is carried out at the end of the lesson. The survey explains that students are very confident and satisfied with the use of the prefix ber-and affix ber-...-an. This study involves secondary school students and focuses on the prefix ber-and affix ber-...an only. This situation enables reseachers to conduct a study on the affixes involving primary school students especially those from SJKT.

Ismail \& Hamzah (2018) have conducted a study to know and analyse language in terms of the affixes, involving Year 5 Chinese students in writing. Commonly, the language errors they make through conversations will be carried away in their writing using the second language. The material for this study is the answer script of section $C$ essay paper, involving several Year 5 students from Sekolah Jenis Kebangsaan Cina Chung Hwa Telok Kemang. The purposive sampling technique is adopted to choose the sample of this study. Corder's Error Analysis Theory (1981) helps to analyse the study material. The text analysis is used as the method in this study. The study finding shows that Chinese students make errors in the prefixes "di-" and "meN-". Chinese students also make mistakes when it comes to choosing terms in their writing. The study is carried out on Chinese students in terms of the prefixes di- and meN- only, and this allows the researchers to focus on Indian students in the mastery of prefixes, suffixes, affixes and loan affixes.

Hwa (2018) who conducted a study on the prefixes meN- and peN- has used the Design and Development Research method involving 3 phases. 210 Chinese students from Year 2, 3 and 4 from 4 SJKC in Selangor were chosen as the study sample. The Elaboration Theory of Instruction is used to produce an affixes-smart model. Two types of methods are used in this studym and they are library study and field study. Students' views about the prefixes meN- and peN- and the perceptions of teachers and students towards the module are measured using a questionnaire. The Fuzzy Delphi method is also used to verify the prototype module by a group of experts. The effectiveness of the module is tested through the quasi-experiment involving the Control group and treatment students from the SJKC. The percentage of the frequency and t-test through the questionnaire data is used to draw a comparison between the pre- and the post-tests. A total of 178 BM teachers from SJK have expressed some positive perception towards the smart-affixes module that can help SJKC students master the prefixes meN- dan peN-. The study carried out by Hwa (2018) with focus on the level of mastery of both prefixes among SJKC students based on the Elaboration Theory of Instruction produces the learning module for both prefixes meN and 
peN only. This gap opens up the opportunity to the researcher to carry out a study on prefixes, suffixes, affixes and loan affixes towards SJKT students.

According to Zabidi (2017), prefixes are the main aspect of affixation in BM morphology and it can lead to inaccurate meaning if wrong affixation is used. This study aims at increasing the mastery in the prefix meN- with the assistance of the LATIM method. This study sample comprises of 10 Year 4 students at a primary school located in Kangar, Perlis. The pre-test, posttest and the questionnaire are used in this study as the study instrument whereas the quantitative study is the design of this study. The LATIM method gives the exposure to all respondents for 30 days and and the post-test has been carried out. The marks for the pre- and post-tests for every respondent are gathered to show the difference. Respondents who have undergone the post-test are given the questionnaire. The questionnaire finding shows that all the students are really interested in mastering the prefix meN- using the LATIM method and this result is proof that the method has increased students' affixation skills in the mastery of the prefix meN-. The study by Zabidi (2017) focuses on the mastery of affixes in the use of the prefix meNonly after the LATIM method is carried out. Thus, this gap has opened the door for a detailed study, with regard to the mastery of prefixes, suffixes, affixes and loan affixes assisted by the affixation innovative kit.

\section{Studies about the Mastery of Bahasa Melayu as the Second Language}

The survey used by Ali \& Othman (2018) in their study determines the relationship between the use of the learning technique and gender. A questionnaire is used as an instrument to collect data. 150 Form 4 students of Melanau ethnicity from 3 secondary schools in Sarawak are selected as the respondents of this study. The mean difference of the writing learning strategy between gender has been identified using the t-test. The study outcome shows that BM teachers should be using various writing skills teaching techniques to help Melanau students master BM as their B2. The finding is thought to be relevant with the study as researchers also adopt the t-test to indentify the significant relationship between the use of the affixation innovative kit and normal teaching methods in the teaching and learning of affixes in class.

The work by Nahar \& Rahman (2018) aims at identifying the level of communicative skills among non-native speakers as past literature has shown that non-Malay students were not proficient in speaking in Malay. The study sample chosen from 5 SJKCs and SJKTs in Kuantan totals 414 students. The questionnaire form and the speaking test are used to gather the data whereas SPSS Version 23 is used to analyse the data. The outcome shows that the level of communicative skills among students in SJK in Kuantan is not satisfactory and every non-Malay student has to apply the use of BM as B2 in their daily lives. This study gives the idea to the researcher to conduct a study on the mastery of affixes so that it can improve SJKT students' performance in Bahasa Melayu.

Social factors influencing BM as B2 among lban students have been examined profoundly by Ujai \& Ruzanna (2017). A total of 225 Level 2 Iban students from schools in Kapit is chosen as the sample and this study is done quantitatively. The questionnaire form involving five social aspects is used as the study instrument. The dominant social factors like attitude, motivation and environment really influence the learning of BM as B2 on the Iban students. Thus, BM educators should take into consideration all the social factors when planning the teaching and learning of 
BM in the classroom. This study focuses on only Iban students who are influenced by the social factors when learning Bahasa Melayu as B2. Therefore, researchers have taken the advantage to go further into the study on SJKT students in the mastery of affixation or affixes.

The study of Mohamad (2017) aims to delve into the technique and method that are appropriate to be applied in the teaching and learning of BM towards Chinese excellent students. A total of 291 students classified as excellent students were chosen as the sample, and a survey is used as the study instrument to achieve the main objective of this study. The study finding shows that the writing method is very much influenced by reading communicative and listening skills even though Chinese students receive great influence from all methods of teaching and learning in BM. This study shows that there is no significant relationship between the BM teaching and learning method towards gender, family socioeconomy and the educational achievement of highly performing students. Even so, the right method of teaching and learning in BM is able to help students learn BM more effectively. This study engages researchers' interest to evaluate the effectiveness of the affixation innovative kit in the mastery of affixes among weak SJKT students.

The study by Ngumbang \& Mahamod (2017) is done based on the Socio-educational Model to look into the interest, attitude and motivation of Melanau students in the teaching and learning of BM as B2. The respondents comprise of 242 Form 4 and 5 students from a secondary school in Sarawak. The descriptive statistics is used to analyse the data of interest, attitude and motivation of Melanau students in the teaching and learning of BM. The students have high level of positive attitude, interest and motivation to learn BM as their second language. They also admit that BM should be learnt well as it is the language of knowledge, national language and a tool of unity for the pluralistic society in our country. This study has given direction to researchers in proving that the use of the affixation innovation kit is able to increase the positivity, interest and motivation of SJKT students to master prefixes, suffixes, affixes and loan affixes.

\section{Studies about Language Games}

Literature has highlighted the fact that playing is essential to children's learning and development by various researchers such as foreign researchers such as Moyles (1989); Bruce (1991); Hall \& Abbott (1991); Wood \& Artfield (1996); Drake (2001); Riley (2003); Broedhead (2004) and Brock et al. (2009). At the same time, local researchers have also carried out a lot of studies about language games. In this issue, the effectiveness in the game technique in strengthening proverb translation skills is examined by Saad et al. (2017). Students from public higher learning institutions (IPTA) in Melaka served as the sample and the observation, pre-test, also post-test were used as the instrument of this study. The students' failure in answering the questions, in obtaining poor results in the tests carried out and the students' lack of involvement are among the findings obtained through the observation and the worksheet analysis. This issue has been addressed by introducing card game activities to foreign students to increase their proverb translation skills. The use of card games activity shows that foreign students are really interested and have the confidence to follow the teaching and learning of proverbs. They also have high motivation to get involved in card games activities that carry the element of proverb translation skills. This study finding motivates the researchers to design an affixation innovative kit to address the issue of affixes mastery among students in SJKT. 
The development of the Basic Reading Kit design comprising of a model, module, exercise book, story book and BM flash cards that can be used by Special Remedial students is examined by Samsudin (2017). Eight subjects who learn in this class are used in this case study and the reading skills evaluation test, psychomotor and affective skills checklist and the non-structured observation form are used as the instrument of this study. The factors of language learning, the use of BBM and the students' own capability are analysed to test the effectiveness of the kit designed. The validity and the reliability of the study finding between the language evaluation test, non-structured observation and the checklist all use the triangulation method. The percentage in the cognitive, affective and psychomotor capabilities are analysed using the quantitative method. The qualitative and quantitative findings show that the kit designed is able to increase the special remedial children's reading skills. This study encourages and motivates researchers to design the affixation innovative kit as a support tool that can facilitate the teaching and learning of affixes.

Ali \& Mahamod (2016) conduct a study to build a BM skills module for pre-schoolers. The module development process entails material preparation, experts' revision and module content evaluation. There are eight experts from the same field and 12 preschool teachers and the total number of experts is 20 . As they designed and constructed the module, constructive criticisms from the experts have been identified to make improvement to the module. The study sample to test the implementation and evaluation towards this module comprises of six students from two preschools. Two preschool teachers are chosen to take part in the teaching and learning in two classrooms. A video recording is used to strengthen the qualitative data. Anecdotal records and students' work sample are used in the data collection method. The finding shows that the game material is able to engage preschool children's interests to follow BM teaching and learning actively and enjoyably. The study finding assures the researchers that they can design an affixation innovative kit that can fulfil students' requirements and directly engage their interests to master prefixes, suffixes, affixes and loan affixes.

The study takes on a qualitative approach to know the role of the language game technique to engage the interests of the Native people in BM teaching and learning as investigated by Nordin \& Ahmad (2016). Interviews, observation and document analysis were used to gather the study data whereas Native teachers and students from four primary schools in Perak became the main respondents for this study. The content analysis was used to analyse teacher and student interviews. The finding shows that native students truly enjoy and have high level of interest in the teaching and learning of BM aided with language games and role plays. They also followed the class activities actively. This study is made a guideline by researchers to carry out interviews with the teachers and perform observation, to obtain an overall data to further consolidate the study finding.

Ramlan \& Kosman (2016) conducted a study to demonstrate the effectiveness of the use of game cards in the effort to inculcate civic values at school. 27 Malay students of Year 3 and 4 who use English to communicate at home are chosen as the study sample. The formative test results were used as data to survey the sample's language mastery. The study finding shows that students have been engaged themselves actively in the teaching and learning. They have the opportunity to learn good values aided by game cards- all hassle-free. The learning approach that leans on collaborating with one another enables students to work actively, and they will automatically use 
BM when they communicate. The use of game cards also play the role as an element in the affixation innovative kit to increase their language skills other than stimulating students' interests in mastering affixes.

\section{Methodology}

This study is a quasi-experimental study which is the study design that uses both pre-and posttests (Creswell, 2007). Campbell \& Stanley (1963), has the view that the study that uses the experimental method is able to explain more clearly about a cause-and-effect oriented phenomenon, and is able to control the effect of external variables. Thus, researcher uses the method of quasi-experiment based on the pre- and post-tests design adapted from Hwa (2018). Through this design, researcher offers treatment to two groups of students namely the Control group and the Experimental group. Control group is exposed to the conventional method of teaching while the Experimental group is exposed to the affixation innovative kit. The design used will be able to determine the level of difference in the achievement of affixation skills between both groups in the pre-and post-tests. The effect of the use of the affixation innovative kit on the mastery of affixation can be ascertained by comparing the mean scores of both pre- and posttests. To find out about the significant difference towards the impact of the use of the kit and the use of traditional teaching on both the Treatment group and control group in the pre- and post-tests, the t-value for both groups will be compared at the significant level of 0.05 . The sample of the study comprises of 68 students from SJKT Ladang Emerald, Selangor. The school is chosen based on the fact that this SJKT has fulfilled all the demands, requirements, and needs of the study as proposed by Noah (2011). In the context of this study, the coice of subjects is based on the suggestions made by Campbell \& Stanley (1963) whereby it must be based on the convenience or the existing group. The 'intact sampling' method is adopted to ensure that the subjects of the study in one classroom remain as the sample of the study according to their respective classes (Best \& Kahn, 1998). Two classes namely Year 5 Pavalam and 5 Maragatham are involved in this study. Year 5 Pavalam comprising of 34 students constitutes the Treatment group. The students of this class are taught affixes assisted by the affixation innovative kit. 34 students from Year 5 Maragatham who are in the Control group will be taught affixation skills in a conventional way. The quasi-experimental study will be done for six times of teaching in 3 months according to the schedule decided by the school. This is done in a controlled environment and it involves two groups of students namely the Treatment group and the Control group and suggested by Wiersma (2000). Before the researcher began his teaching, the same pre-test will be given to both groups to know their level of affixation mastery. After this test, then both groups will be receiving treatment according to several different approaches, in which the Experimental group is taught the affixation skills using the affixation innovative kit whereas the Control group is taught conventionally. Having received the treatment, both groups will be given the post-test with the purpose of evaluating the implication of both these approaches towards the teaching and learning of affixes. On this token, the use of the affixation innovative kit and the conventional approach is the independent variable whereas student achievement in affixation skills is categorised as the dependent variable. In this study, the pre- and post-tests also the affixation innovative kit stand to be the instrument in obtaining the data. 
INTERNATIONAL JOURNAL OF ACADEMIC RESEARCH IN PROGRESSIVE EDUCATION AND

DEVELOPMENT

Vol. 9, No. 4, 2020, E-ISSN: 2226-6348 @ 2020 HRMARS

\section{Study Findings}

Table 1.1: data notes from observation

Item Observation notes

Observing students from the Treatment group following the teaching and learning of affixes in class.
Observing students from the Treatment group during recess
- Students enjoyed and were happy in following the teaching using the affixation innovative kit. Students who were previously shy and less active look in high spirit when teacher handled the teaching and learning affixes with the help of the affixation innovative kit.

- Students responded and collaborated in the $3 \mathrm{P}$ activities to test the mastery in affixation. There was evidence of students' tendency on teacher's teaching aided by the affixation innovative kit through students' behavior- raising their hands to answer the questions asked by the teacher.

- Students felt more comfortable, confident and bold to see the teachers to disucss and interact. This practice enables the content of the lesson to become easy to remember as knowledge is received naturally and not by force.
- Students like to spend their free time finding affixated words using the affixation innovative kit. For some who love Mathematics, they will spend their time by changing the code to affixated words at the Reading Corner.

- Students interested in card games were occupied in playing affixes game cards with their classmates. This clearly shows that the affixation innovative kit is able to encourage the students to embrace selflearning without teacher's guidance.

All the data obtained from the affixation mastery test is quantitative in nature. The data are gathered and analysed using The Statistical Package For The Social Science or SPSS. To see the distribution of scores of students' achievement in basic reading skills (students from the Experimental group and Control group in pre- and post-tests), the frequency mean descriptive 
analysis is used. The inferential statistics for the independent sample t-test and paired sample ttest is used to distinguish the mean level of student achievement in the affixation mastery in both the pre- and post-tests, for both experimental and control groups. The significance level for all these tests is 0.05 .

\section{The Outcome for the Quasi-Experiment}

The data obtained in this study is analysed using the paired sample t-test inferential statistics. In this work, the hypothesis is tested at the significance level of 0.05. According to Chua (2012), the paired sample t-test is used when every individual in the sample is measured twice and both the normal distribution data are used for comparison. This means that every individual from the Experimental group and the Control group has two scores for two different levels in the independent variable (pre- and post-tests).

The study findings are elaborated as follows:

Study question 1: Is there any significant difference between the overall mean of achievement between the Treatment group and the Control group in the pre-test?

Ho: There is a significant difference between the overall mean of achievement between the Treatment group and the Control group in the pre-test.

$\mathrm{H} 1$ : There is a significant difference between the overall mean of achievement between the Treatment group and the Control group in pre-test

Level of understanding, $\alpha=0.05$

Table 1.2 below shows the mean score and the standard deviation for the overall achievement of the Treatment group and the Control group in the pre-test. This table explains that the achievement of both the groups is not very much different. This can be seen on the mean score of achievement of both groups. The mean score of achievement for the Treatment group is 33.94 with the standard deviation 8.676 whereas the mean score of achievement for the Control group is 34.79 with the standard deviation 8.786 .

Table 1.2: Mean, standard deviation and the paired sample t-test for the mean score of achievement of the Treatment group in the pre-tests

\begin{tabular}{lllllc}
\hline Group & N & Mean & $\begin{array}{l}\text { Standard } \\
\text { deviation }\end{array}$ & $\begin{array}{l}\text { T- } \\
\text { value }\end{array}$ & $\begin{array}{l}\text { Significant } \\
\text { level }\end{array}$ \\
\hline Treatment group & 34 & 33.94 & 8.676 & -.432 & .668 \\
Control group & 34 & 34.79 & 8.786 & & \\
\hline
\end{tabular}

The $p$-value illustrated in the table above is greater from the level of understanding determined $(0.668>0.05)$. Thus, Ho is accepted. This shows that there is no significant difference between the overall mean of achievement between the Treatment group and the Control group in the pretest. This indicates that both the groups have the same level of achievement before they are given treatment.

Study question 2: Is there any significant difference for the mean of achievement for the Treatment group in pre- and post-tests? 
Ho: There is no significant difference for the mean of achievement for the Treatment group in pre- and post-tests.

$\mathrm{H} 1$ : There is a significant difference for the mean of achievement for the Treatment group in pre- and post-tests.

Level of understanding, $\alpha=0.05$

To identify if there is a significant difference towards the mean score of achievement in the Treatment group in pre- and post-tests, the paired t-test analysis is carried out. The analysis of the study findings can be referred to in Table 1.3:

Table 1.3: Mean, standard deviation and the paired sample t-test for the mean score of achievement of the Treatment group in pre- and post-tests.

\begin{tabular}{lccccc}
$\begin{array}{l}\text { Treatment } \\
\text { group }\end{array}$ & Bil & Mean & $\begin{array}{l}\text { Standard } \\
\text { deviation }\end{array}$ & $\begin{array}{l}\text { T- } \\
\text { value }\end{array}$ & $\begin{array}{l}\text { Significant } \\
\text { level }\end{array}$ \\
\hline Pre & 34 & 33.94 & 8.676 & 33.982 & .000 \\
Post & 34 & 75.85 & 10.419 & & \\
Pre-Post & 34 & 41.91 & & & \\
\hline
\end{tabular}

Based on Table 1.3, the mean score of achievement obtained by the Treatment group in the pretest is 33.94, standard deviation 8.676 whereas during the post-test, the mean score of achievement is 75.85 with a standard deviationan 10.419 . The difference in the mean score between both tests is 41.91 .

The $p$-value shown in the above Table is smaller than the level of understanding determined $(0.000<0.05)$. Thus, Ho is rejected. The analysis of the paired sample t-test shows that there is a significant difference for the mean score of achievement of the treatment group in pre- and posttests. This means that the students in the experimental group have a significant level of achievement after they are given treatment.

Study question 3: Is there any significant difference for the mean of achievement for the Control group in the pre- and post-tests?

Ho: There is no significant difference for the mean of achievement for the Control group in preand post-tests.

$\mathrm{H} 1$ : There is a significant difference for the mean of achievement for Control group in pre- and post-tests

Level of understanding, $\alpha=0.05$

To identify if there is a significant difference towards the mean score of achievement in the Control group in pre- and post-tests, the paired t-test analysis is done. The study finding analysis is stated in Table 1.4: 
Vol. 9, No. 4, 2020, E-ISSN: $2226-6348$ @ 2020 HRMARS

Table 1.4: the mean, standard deviation, the paired sample t-test for the mean score of achievement for the Control group in pre- and post-tests

\begin{tabular}{llllll}
\hline Control group & Bil & mean & $\begin{array}{l}\text { Standard } \\
\text { deviation }\end{array}$ & $\begin{array}{l}\text { T- } \\
\text { value }\end{array}$ & $\begin{array}{l}\text { Significant } \\
\text { level }\end{array}$ \\
\hline & & & & - & \\
Pre & 34 & 34.90 & 9.174 & 7.141 & 0.00 \\
Post & 34 & 45.10 & 7.019 & & \\
Pre-Post & 34 & 10.2 & & & \\
\hline
\end{tabular}

Based on Table 1.4, the mean score of achievement obtained by the Control group in the pretest is 34.90 with the standard deviation is 9.174 . Mean score in the post-test is 45.10 with the standard deviation 7.019. The difference in the mean score between both tests for the Control group is 10.10 . The paired sample t-test analysis shows that there is a significant difference for the mean score of the overall achievement of the students in the Experimental group in pre- and post-tests.

The $p$-value shown in the table above is smaller than the level of understanding determined $(0.000<0.05)$. Thus, Ho is rejected. This shows that there is a significant difference for the mean of achievement for the mean of achievement for the Control group in pre- and posttests.

Question 4: Is there any significant difference for the mean of achievement for the Treatment group and the Control group in the post-test?

Ho: There is no significant difference for the mean of achievement for the Treatment group dan Control group in the post-test.

$\mathrm{H} 1$ : There is a significant difference for the mean of achievement for the Treatment group dan Control group in the post-test.

Level of understanding, $\alpha=0.05$

Table 1.5 portrays the achievement of the mean score and the standard deviation between the Treatment group and the Control Group in the post-test. This table explains that the achievement of both groups shows a significant difference through the mean score obtained. The achievement mean score of the Treatment group is 75.85 with the standard deviation 10.419. The achievement mean score for the Control group is 44.47 with the standard deviation 6.912. This means that the experimental group is more capable in mastering affixation compared to the Control group. 
INTERNATIONAL JOURNAL OF ACADEMIC RESEARCH IN PROGRESSIVE EDUCATION AND

DEVELOPMENT

Vol. 9, No. 4, 2020, E-ISSN: $2226-6348$ @ 2020 HRMARS

Table 1.5: Independent t-test for the difference in the mean score of achievement between the Treatment group and Control group in the post-test

\begin{tabular}{lccccc}
\hline Group & N & Mean & $\begin{array}{c}\text { Standard } \\
\text { deviation }\end{array}$ & $\begin{array}{c}\text { Nilai- } \\
\mathrm{t}\end{array}$ & $\begin{array}{l}\text { Significant } \\
\text { level }\end{array}$ \\
\hline Treatment group & 34 & 75.85 & 10.419 & 15.635 & .000 \\
Control group & 34 & 44.47 & 6.912 & & \\
\hline
\end{tabular}

The $p$-value shown in the above Table s smaller than the level of understanding stipulated ditetapkan $(0.000<0.05)$. Thus, $\mathrm{Ho}$ is rejected. This shows that there is a significant difference between the mean of achievement for the Treatment group and Control group in the post-test. This result also proves that there is an increase in the students' achievement performance from the Treatment group after the treatment process was carried out six times.

Other than that, games are admittedly important to children's learning and development as maintained by scholars like Moyles (1989); Bruce (1991); Hall \& Abbott (1991); Wood \& Artfield (1996); Drake (2001); Riley (2003); Broedhead (2004); Brock et al. (2009). According to Brock et al. (2009), games prepare the opportunity for the students to undergo the rearrangement process, new discovery, enrichment, experience- and knowledge-building and discovery of new concepts. Also, games can also avoid boredom and eliminate fear among the children towards the subjects taught, especially language subjects. The playing elements prepared by teachers not only aiming to make the classrooms more fun but also give a wider meaning to students when they interact with their environment and surroundings (Hurlock, 1987).

\section{Conclusion}

Teaching and learning affixes aided by the affixation innovative kit, has proven to positively affect students' achievement and made it easier for the teachers to handle the process of teaching and learning more effectively. Also, the use of the affixation innovative kit in teaching and learning not only increases the mastery of affixes in students' essays but also creates a more fun and enjoyable teaching and learning atmosphere. Learning through play is able to instil students' interests to continue to learn language. The affixation innovative kit that is language game activity can be generally accepted as an efficient method to introduce and to learn affixes better and in more detail. The content of this affixation innovative kit is perfectly in line with the requirements of the education today towards the academic support material that can develop students' potential. The affixation innovative kit is designed with the DSKP and SJK text books in mind, giving students the guideline to master affixes from Year 1 to Year 6 . The mastery of affixes guided by this affixation innovative kit will definitely catapult students' performance in affixes encompassing prefixes, suffixes, affixes and loan affixes. This kit will also be equipped with its manual and worksheet so that teachers and students can better understand the tasks assigned to them. This learning kit will help teachers to plan their teaching of affixes with various strategies and the latest teaching techniques. The use of this kit will even focus on the effort to produce students who have the skills in communicating, collaborating, also thinking creatively, critically and innovatively. Every teaching and learning activity prepared in the components of the kit contains aspects such as details of the steps of implementation of teaching and learning affixes, 
appropriate games materials, students' worksheet in the form of 3P exercises and the use of easy language which is compatible with students' capability. In other words, this affixation innovative kit not only becomes the main choice for school citizens but also foreign students who are currently learning Bahasa Melayu as the second language in higher learning institutions-they also need this kit to master affixes.

\section{References}

Ali, A., \& Mahamod, Z. (2016). Pembangunan dan kebolehgunaan modul berasakan bermain bagi pembelajaran kemahiran bahasa Melayu kanak-kanak prasekolah. Jurnal Pendidikan Bahasa Melayu. 6(1), 16-29.

Ali, N. H., \& Othman, Y. (2018). Strategi pembelajaran kemahiran menulis bahasa Melayu sebagai bahasa kedua dalam kalangan pelajar Melanau daerah Daro. Jurnal Pendidikan Bahasa Melayu. 8(1), 33-41.

Best, J. W., \& Kahn, J. V. (1998). Research in education (8th ed.). Boston: Allyn and Bacon.

Broadhead, P. (2004). Early years play and learning: Developing social skills and cooperation. London: Routledge.

Brock, A., Sylvia, D., Jarvis, P., \& Olusoga, Y. (2009). Perspectives on play: Leaning for life. Boston: Pearson Education Limited.

Bruce, T. (1991). Time to play in early childhood education. London: Hodder \& Stoughton.

Campbell, D. T., \& Stanley, J. C. (1963). Experimental and quasi-experimental design for research. Chicago: Rand Mc Nally College Pub. Co.

Chua, Y. P. (2006). Buku 2: Asas statistik penyelidikan. Kuala Lumpur: McGraw Hill Sdn Bhd.

Cresswell, J. W. (2007). Designing and conducting mixed method research. Thousand Oaks, CA: SAGE Publications.

Drake, J. (2001). Planning children's play and learning in the foundation stage. London: David Fulton Publishers.

Hamid, N. A., Badushah, J., \& Sulaiman, F. (2010). Kelemahan tatabahasa pelajar Cina dalam penulisan karangan pada peringkat menengah rendah. Prosiding Seminar Antarabangsa Pendidikan Bahasa Melayu, 12-18 Jun.

Hurtlock, E. B. (1987). Child development. New York: McGraw-Hill Book Co.

Hwa, O. C. (2018). Keberkesanan modul dalam meningkatkan penguasaan imbuhan meN- dan PeN- murid SJKC (Tesis ljazah Doktor Falsafah, Universiti Teknologi Malaysia).

Ismail, A., \& Hamzah, Z. A. Z. (2018). Analisis kesalahan dalam penulisan pelajar bahasa kedua dari aspek morfologi. Jurnal Linguistik, , 22(1), 24-31.

Jumari, N.A., \& Haron, M. (2018). Pengajaran dan Pembelajaran Imbuhan Melalui Pendekatan Pembelajaran Aktif. Seminar Bahasa Melayu, 2018, 19, 235-247.

Kementerian Pendidikan Malaysia. (2011). Dokumen Standard Kurikulum dan Pentaksiran Bahasa Melayu (SJKT), Bahagian Pembangunan Kurikulum, Putrajaya.

Mohamad, M. Y. (2017). Kekerapan penggunaan strategi pembelajaran bahasa Melayu dalam kalangan murid cemerlang etnik Cina. Jurnal Pendidikan Bahasa Melayu. 7(1), 85-92. 
INTERNATIONAL JOURNAL OF ACADEMIC RESEARCH IN PROGRESSIVE EDUCATION AND

DEVELOPMENT

Vol. 9, No. 4, 2020, E-ISSN: $2226-6348 @ 2020$ HRMARS

Moyles, J. (1989). The excellence of play. Open University Press, Milton Keynes.

Nahar, N. A., \& Rahman, F. A. (2018). Tahap penguasaan kemahiran bertutur bahasa Melayu dalam kalangan murid bukan penutur natif. Jurnal Pendidikan Bahasa Melayu, 8(1), 7483.

Ngumbang, N. A., \& Mahamod, Z. (2017). Sikap, minat dan motivasi murid Melanau dalam pembelajaran bahasa Melayu sebagai bahasa kedua. Pendeta Jurnal Bahasa Melayu, Pendidikan dan Sastera, 8, 47-58.

Noah, S. M. (2011). Reka Bentuk Penyelidikan: Falsafah Teori dan Praktis. Malaysia: Universiti Putra Malaysia Publication.

Nordin, M. R. M., \& Ahmad, M. (2016). Penggunaan teknik permainan bahasa dan main peranan dalam kalangan murid Orang Asli: Satu tinjauan. Jurnal Penyelidikan Dedikasi, 11, 79-97.

Ramlan, S. R., \& Kosman, Z. (2016). Penggunaan kad permainan bahasa dalam pengajaran dan pembelajaran bahasa Melayu. Seminar Bahasa Melayu, 359-368.

azin, A. S. A., \& Subramaniam, V. (2019). Kesalahan penggunaan imbuhan awalan dan akhiran dalam kalangan murid Sekolah Jenis Kebangsaan Tamil berdasarkan Teori Analisis Kesalahan Corder (1973). Jurnal Antarabangsa Alam Dan Tamadun Melayu $7(1), 3-13$

Riley, J. (Ed.). (2003). Learning in the early years. London: Paul Chapman Educational Publishing.

Saad, N. H. M., Karim, R. A., Akmar, F., \& Zain, Z. M. (2017). Keberkesanan penggunaan kaedah permainan bahasa dalam pembelajaran penterjemahan peribahasa. Jurnal Antarabangsa Alam Dan Tamadun Melayu, 5(3).

Samsudin, N. H. (2017). Penggunaan kit asas membaca bahasa Melayu untuk kanakkanak pemulihan khas. (Tesis ljazah Doktor Falsafah, Universiti Malaya).

Ujai, D. S., \& Ruzanna, W. M. (2017). Pengaruh faktor sosial dalam pembelajaran bahasa Melayu dalam kalangan murid Iban, Jurnal Pendidikan Bahasa Melayu, 7(1), 2180-4842.

Wiersma, W. (2000). Research methods in education: An introduction (7 $7^{\text {th }}$ ed.). Boston: Allyn and Bacon.

Wood, E., \& Artfield, J. (1996). Play, learning and the early childhood curriculum. London: Paul Chapman Educational Publishing.

Zabidi, N. (2017). Kaedah LATIM sebagai inovasi pendidikan dalam meningkatkan penguasaan penggunaan imbuhan awalan meN. Jurnal Bahagian Teknologi Pendidikan, 10(1) 58-70. 